\title{
Spatial and temporal photoacclimation of Stylophora pistillata: zooxanthella size, pigmentation, location and clade
}

\author{
Gidon Winters ${ }^{1,2,4, *}$, Sven Beer ${ }^{1}$, Batsheva Ben Zvii ${ }^{1}$, Itzik Brickner ${ }^{3}$, Yossi Loya ${ }^{3}$ \\ ${ }^{1}$ Department of Plant Sciences, Tel Aviv University, Tel Aviv 69978, Israel \\ ${ }^{2}$ The Inter-University Institute of Eilat, PO Box 469, Eilat 88103, Israel \\ ${ }^{3}$ Department of Zoology and the Porter School for Environmental Studies, Tel Aviv University, Tel Aviv 69978, Israel
}

${ }^{4}$ Present address: Institute for Evolution and Biodiversity, Westfälische Wilhelms-Universität, Hüfferstrasse 1, 48149 Münster, Germany

\begin{abstract}
Photoacclimation of the symbiotic hermatypic coral Stylophora pistillata was studied both for colonies growing at different depths (1 to $20 \mathrm{~m}$ ) sampled within the same season ('spatial photoacclimation') and for colonies growing at the same depth (5 m) but sampled throughout the year ('temporal photoacclimation'). Specimens were darker and had increased chlorophyll densities (chlorophyll per coral surface area) under low-light conditions caused both by increased depth and, in shallow-growing specimens, by the winter season. However, while increased depth involved increased zooxanthella chlorophyll content, acclimation to low irradiances by shallow-growing corals during the winter mostly involved an increase in algal density. In shallow-growing corals, both zooxanthella chlorophyll content and coral chlorophyll density fluctuated seasonally in correlation with light more than with nitrogen or temperature. This could be related to the fact that reefs in Eilat, Israel, are exposed to more solar radiation than many other reefs in the world. Histological analyses of high-light corals showed that zooxanthellae were located deeper inside the host tissue and were smaller in diameter compared to zooxanthellae from low-light corals. Additionally, while deep-water colonies hosted clade $\mathrm{C}$ zooxanthellae, colonies growing in shallow waters, both in high- and very low-light environments, hosted clade A. These clade differences were found to affect coral physiology, as examined in a short-term thermal stress experiment, with clade-A colonies having higher thermal resilience than clade-C colonies. Taken together, our results show evidence of different mechanisms that help adjust the light-capturing abilities of $S$. pistillata zooxanthellae to spatial and temporal changes in irradiance.
\end{abstract}

KEY WORDS: Spatial photoacclimation ' Temporal photoacclimation ' Stylophora pistillata Zooxanthella clade $\cdot$ Zooxanthella location · Zooxanthella pigments

Resale or republication not permitted without written consent of the publisher

\section{INTRODUCTION}

The success of hermatypic corals in oligotrophic waters is largely due to their mutualistic symbioses with photosynthesizing microalgae (zooxanthellae; Trench 1993). Indeed, for some photosymbiontcontaining corals growing in the shallower parts of the photic zone, translocation of photosynthates from the symbionts to the host can provide for their entire metabolic requirements (von Holt \& von Holt 1968).

Because of their symbiotic relationships with zooxanthellae, hermatypic corals must acclimate to the changes in irradiance and spectrum composition associated with increasing depth (Weinberg 1976). Indeed, such 'spatial photoacclimation' has been shown to occur in both the host (Anthony et al. 2005) and the algal symbiont (Mass et al. 2007). However, even within the same depth, corals must acclimate to changes in light over time ('temporal photoacclimation') both on a diel (Winters et al. 2003) and on a seasonal (Warner et al. 2002, Winters et al. 2006) scale. For shallow-growing corals in particular, temporal photoacclimation may be of importance in order to ensure not only the effective capture of relatively low irradiances during the winter 
(Winters et al. 2006), but also to minimise the effects of photoinhibition caused by high light both throughout the day and during the summer (e.g. Winters et al. 2003). Although studying natural temporal photoacclimation in corals may require year-round measurements, photosynthesis of hermatypic corals has mostly been studied over relatively short time scales, from hours to several days, or during 1 season only (e.g. Gorbunov et al. 2001, Lesser \& Gorbunov 2001). Longterm effects of seasonal fluctuations of photosynthetic activity in corals have thus far been investigated only by Fagoonee et al. (1999), Fitt et al. (2000), Warner et al. (2002), Shenker et al. (2006) and Winters et al. (2006). Altogether, those works showed seasonal variability in a suite of zooxanthella-related parameters (e.g. density, chlorophyll content and the maximal quantum yield of photosystem II, $F_{\mathrm{v}} / F_{\mathrm{m}}$ ), in addition to suggesting different environmental parameters responsible for the observed fluctuations such as the seasonal changes in nitrate (Fagoonee et al. 1999), light (Winters et al. 2006) or the combination of light and temperature (Fitt et al. 2000, Warner et al. 2002). The need for such long-term measurements stems not only from the relatively large variability in the environmental parameters that are relevant to photosynthesis (e.g. light and temperature), but also from the need to establish what is 'normal' in order to be able to identify what is 'outside of the normal'.

Studying temporal changes in zooxanthella photophysiological parameters could also be important from a mechanistic point of view. Since the pioneering work of Falkowski \& Dubinsky (1981) on corals growing at different depths, increased algal pigment content has been considered the major mechanism for low-light zooxanthella photoacclimation (as well as that of other primary producers, Prezelin 1987). However, it is possible that temporal photoacclimation entails different mechanisms than that caused by different depths. To date, a comparison between spatial (deep/shallow) and temporal (summer/winter) photoacclimation mechanisms in the same species of coral has not been conducted. The main purpose of this study was therefore to examine acclimations of zooxanthellae in the coral Stylophora pistillata both to various irradiances along a depth gradient and to seasonal variations in irradiances. This coral was chosen since it is dominant in the Red Sea, where it occupies a wide depth range of 1 to 65 m (Loya 1972, 1976).

\section{MATERIALS AND METHODS}

Temporal photoacclimation. Stylophora pistillata colonies $(n=6)$ were collected at $5 \mathrm{~m}$ depth from the reef outside the Inter-University Institute (IUI) in Eilat,
Israel (Gulf of Aqaba, northern Red Sea, $29^{\circ} 30^{\prime} \mathrm{N}$, $34^{\circ} 55^{\prime}$ E). Colonies were broken into $\sim 185$ to $7 \mathrm{~cm}$ branches (fragments), mounted onto plastic holders with non-toxic glue (AquaMend) and then placed back into the sea at the depth of collection. All corals were left for $3 \mathrm{mo}$ in the sea before measurements began. Once a month (September 2004 to August 2005), a fragment from each colony was collected for measurements of the temporal changes in zooxanthella parameters. Coral fragments were placed in tagged ziplock bags filled with ambient seawater and shaded from the natural irradiance to prevent possible photoinhibition upon ascending. Once ashore, the fragments were frozen at $-70^{\circ} \mathrm{C}$ within 30 min of collection and stored for later analysis (see below).

Spatial photoacclimation. Fragments $(4$ to $6 \mathrm{~cm}$ ) were broken off Stylophora pistillata colonies growing naturally at 1, 5, 10 and $20 \mathrm{~m}$ ( 6 to 7 colonies per depth; total $\mathrm{n}=27$ ). The fragments (collected between 26 July and 7 August 2005) were placed in shaded zip-lock bags, frozen upon returning to shore and analysed later (see below).

Irradiance, temperature and nutrient measurements. Irradiance (global solar radiation, above the sea surface at the IUI pier) and seawater temperature (at $5 \mathrm{~m}$ depth, adjacent to the corals) were measured continuously using a CM 21 Pyranometer (310 to $2800 \mathrm{~nm}$, Kipp and Zonen) and а НОВO Water Temp Pro data logger (Onset Computers), respectively. The same measurements were done, and have been presented before (albeit on a longer time scale), by Winters et al. (2006).

Nitrogen measurements were performed monthly on surface water sampled from Stn A, located some $2.5 \mathrm{n}$ miles from the coral reef $\left(29^{\circ} 28^{\prime} \mathrm{N}, 34^{\circ} 55^{\prime} \mathrm{E}\right)$. This was done since technical problems prevented us from measuring nitrogen closer to the corals throughout the entire sampling period; however, comparisons to 9 mo of nitrogen data taken close to the corals revealed a highly significant $(\mathrm{p}<0.0001)$ positive relationship between the 2 sites $\left(\mathrm{r}^{2}>0.9\right.$ for $\mathrm{NO}_{2}{ }^{-}$[nitrite], $\mathrm{NO}_{3}{ }^{-}$[nitrate] and total oxidised nitrogen, TON). The seawater was sampled as part of the Israel National Monitoring Program (www.iui-eilat.ac.il) using 51 Niskin bottles (Go-Flow Oceanic). The samples were stored at $4^{\circ} \mathrm{C}$ until nitrogen analysis. $\mathrm{NO}_{2}{ }^{-}$was analysed with the colorimetric method described by Grasshoff et al. (1999) using a Lachat 8000 QuikChem flow injection autoanalyser (FIA, Lachat Instruments). $\mathrm{NO}_{3}{ }^{-}$concentrations were calculated from the TON concentrations minus the $\mathrm{NO}_{2}^{-}$concentration of the same sample.

Zooxanthella parameters. Coral tissue was removed (using a VL Paasche airbrush with $0.2 \mu \mathrm{m}$ filtered seawater, FSW) and homogenised, and the resulting 
slurry was centrifuged (Johannes \& Wiebe 1970). The pellet containing zooxanthellae was collected, resuspended in FSW, homogenised and centrifuged again. The pellet was again resuspended in $1.0 \mathrm{ml}$ of FSW and zooxanthella-containing aliquots were used for measurements of (1) total chlorophyll (chl) $a$ and $c_{2}$ (overnight extraction in $90 \%$ acetone, absorbance readings at 664 and $630 \mathrm{~nm}$ according to Jeffrey \& Humphrey 1975) and (2) total number of zooxanthellae (cells counted under a light microscope using a Neubauer haemocytometer). These measurements were normalised to coral surface area, resulting in the parameters zooxanthella density and chlorophyll density. Zooxanthella chl $\left(a+c_{2}\right)$ content was calculated by dividing chlorophyll by the number of zooxanthellae measured for the same coral.

The surface area of coral fragments was measured using the wax technique (Stimson \& Kinzie 1991). Wax weight was transformed to surface area using a calibration curve $\left(\mathrm{r}^{2}=0.92\right)$ based on 7 standardised cubes produced from sandpapering Stylophora pistillata coral skeletons to known surface areas. For improving the accuracy of this method, wax was removed from the coral skeleton by multiple washes in boiling water followed by drying the fragments in air for $2 \mathrm{~h}$ and then weighing the dried fragments before and after dipping them again into boiling wax. This process was repeated so that in total the wax weight of each fragment was measured 3 times.

Light data. Using the Comprehensive Ocean-Atmosphere Data Set (COADS; Cayan 1992) surface solar radiation at Eilat $\left(30^{\circ} \mathrm{N}, 35^{\circ} \mathrm{E}\right)$ was compared to other reefs around the world, including Heron Island (Queensland, Australia; $15^{\circ} \mathrm{S}, 150^{\circ} \mathrm{E}$ ), Coconut Island (Kane'ohe Bay, Hawaii; $20^{\circ} \mathrm{N}, 160^{\circ} \mathrm{W}$ ) and Puerto Morelos (Quintana Roo, Mexico; $25^{\circ} \mathrm{N}, 80^{\circ} \mathrm{W}$ ). Errors contained within this 'CAYAN $\mathrm{Si}^{\prime}$ data set (http:// ingrid.ldeo.columbia.edu/SOURCES/.CAYAN/.Si/) were reduced by monthly averaging over $5^{\circ}$ 'squares'. The above comparisons were made for January 1990 to January 1998 accessible data.

Histological examinations. Three sets of Stylophora pistillata fragments $(\sim 2 \mathrm{~cm}$ long, taken from at least $2 \mathrm{~cm}$ below the tip area) were prepared for histological examination: (1) fragments collected during June 2006 from colonies growing naturally at depths of 2 and $30 \mathrm{~m}$ (4 corals from each depth), (2) fragments belonging to the same colonies $(\mathrm{n}=5$ colonies, 1 fragment from each colony) growing at $5 \mathrm{~m}$, collected in December 2006 and June 2007, and (3) fragments collected from colonies naturally growing at $3 \mathrm{~m}$ depth $(\mathrm{n}=4$ colonies, 2 fragments from each colony; collected in December 2006), mounted in an upright position (as mentioned above) and grown in an outdoor water table $(1 \times 3 \times 0.1 \mathrm{~m})$ that was supplied with running seawater
(5 $1 \mathrm{~min}^{-1}$ ). These fragments were kept under 2 different irradiances created by using 50 and $85 \%$ lightretaining black shading nets. Fragments were kept in this manner for 6 mo before being preserved and prepared for histological examination.

For fixation, all samples were brought to the laboratory (within shaded zip-lock bags filled with seawater), where they were fixed in $4 \%$ formal aldehyde solution in FSW for $24 \mathrm{~h}$, after which samples were rinsed in running tap water, preserved in $70 \% \mathrm{EtOH}$ and stored at $4{ }^{\circ} \mathrm{C}$ for 4 to $5 \mathrm{mo}$ prior to further handling. The preserved samples were decalcified by immersion in a 1:1 solution of formic acid and sodium citrate (Rinkevich \& Loya 1979). Decalcification was continued until release of gaseous $\mathrm{CO}_{2}$ from the tissues had terminated. The tissues were then processed using a Citadel 2000 Tissue Processor and embedded in paraffin (Paraplast Plus, McCormick Scientific; melting point of $56^{\circ} \mathrm{C}$ ). The branched tissues (without the calcareous skeleton) were filled up with melting paraffin and placed vertically in the embedding moulds enabling its cross sectioning. Histological cross sections ( $6 \mu \mathrm{m}$ thick) were cut with a Shandon M1R rotary microtome and were stained with Gill's Haematoxylin and Eosin. Three histological slides were prepared for each sample containing several replicates of the tissues (thus producing 8 to 12 'tissue ring' sections per slide). The vertical distance between the 3 cross sections was more then $300 \mu \mathrm{m}$. Histological slides were examined under a light microscope fitted with a digital camera (Nikon DS-5M-L1). Minimal distances between algal cells and the external part of the ectoderm, as well as the diameter of the algal cells, were recorded in each slide from each depth and quantified using image analysis software (UTHSCSA Image tool, version 3.0, 2002). Due to the fact that not all algae are perfectly round, the diameter calculated was an average of 2 perpendicular diameters. All measurements were calibrated against a $100 \mu \mathrm{m}$ scale photographed within each slide. For histological analysis, replicates from the same tissue preparation and from the same coral were averaged (hence $\mathrm{n}=4$ coral colonies from each depth and light treatment, and $\mathrm{n}=5$ coral colonies for each season).

DNA extraction and PCR amplification. Stylophora pistillata branches ( $4 \mathrm{~cm}$ pieces) were obtained during June and July 2006 from colonies growing naturally at deep (20 and $30 \mathrm{~m}, \mathrm{n}=5$ from each depth) and shallow $(2 \mathrm{~m})$ reef areas opposite the IUI. At the shallow site, branches were collected both from colonies growing naturally under the high-light conditions that prevail at these depths $(\mathrm{n}=4)$ and from underneath IUI's pier (an artificial metal structure that has been in place for over $15 \mathrm{yr}$, typically shading the corals growing beneath it for nearly all daylight hours; $\mathrm{n}=4$ ); hence in total 18 samples were used for the following 
DNA extraction. The colonies from which the branches were sampled were marked for future work (see thermal stress experiment below). The collected branches were brought within shaded zip-lock bags filled with seawater to the laboratory, where coral tissues were removed and zooxanthella-containing pellets were prepared as described above. All samples were kept on ice as much as possible.

Total nucleic acids were extracted using cetyltrimethylammonium bromide (CTAB), following a protocol modified from Coffroth et al. (1992). Lysis of algal pellets was in $600 \mu$ of $2 \times$ CTAB. DNA was extracted with $600 \mu \mathrm{l}$ of phenol:chloroform:isoamylalcohol (25:24:1), followed by centrifugation $(2300 \times g$, $5 \mathrm{~min})$, removing the aqueous layer to a clean tube, followed by a second extraction with chloroform:isoamylalcohol (24:1). DNA was precipitated with 95\% EtOH at $-20^{\circ} \mathrm{C}$ overnight; the pellets were washed twice with $70 \% \mathrm{EtOH}$, dried and resuspended in $50 \mu \mathrm{l}$ of double distilled water. The DNA samples were stored at $-20^{\circ} \mathrm{C}$ for future use.

Following DNA extraction, PCR was used to amplify small subunit internal transcribed spacer 2 (ITS-2) ribosomal DNA (SSU rDNA) of Symbiodinium using the following primers: ITS-INFOR (5'-GTG AAT TGC AGA ACT CCG TGA ACC-3') and ITS-REV (5'-GGT TCA CTT GTC TGA CTT CAT GCT-3'). PCR products amplified with these primers included the 3 '-end of the $5.8 \mathrm{~S}$ region, the whole ITS-2 high-variability region and the 5 '-end of the LSU rDNA. PCR reactions (50 $\mu \mathrm{l})$ included 22.5 $\mu$ l PCR reaction mix (Taq Mix Purple, Lamda Biotech), 0.75 to $1 \mu$ l of each primer (working stock of $10 \mathrm{pmol}$ ) and 0.5 to $1 \mu \mathrm{l}$ of undiluted DNA. PCRs were performed using a T-Personal thermal cycler (Biometra) with an initial denaturation of $2 \mathrm{~min}$ at $94^{\circ} \mathrm{C}$ followed by 31 cycles of $30 \mathrm{~s}$ at $95^{\circ} \mathrm{C}, 30 \mathrm{~s}$ at $60^{\circ} \mathrm{C}, 45 \mathrm{~s}$ at $72^{\circ} \mathrm{C}$ and finally a $5 \mathrm{~min}$ extension period at $72^{\circ} \mathrm{C}$. The $300 \mathrm{bp}$ PCR products were separated on $1.5 \%$ agarose gels and visualised with ethidium bromide under UV light. PCR products were extracted and purified from agarose gel (using the DNA Isolation Kit, Biological Industries), cloned into pGEM-T Easy Vector System (Promega), and transformed into Escherichia coli DH5 $\alpha$ competent cells. Following blue/white selection on LB agar plates (Ampicillin, XGal/IPTG), at least 4 colonies were randomly picked for sequencing. Plasmid DNA was extracted (with the HiYield Plasmid Mini Kit, RBC Bioscience) and sequenced on an ABI PRISM 3100 Genetic Analyzer (Applied Biosystems) using the ITS-INFOR primer.

Phylogenetic analysis. For the phylogenetic analysis, a total of 18 environmental Symbiodinium sp. sequences derived from Stylophora pistillata growing at 2 to $30 \mathrm{~m}$ within the Gulf of Aqaba (accession numbers FJ390875-FJ390892; this work) were combined with 12 Symbiodinium sp. sequences for the SSUrDNA ITS-2 region available in GenBank (AF333505, AF333507-9, AF333511-2, AF333514-8, AF334659; LaJeunesse 2001). Gymnodinium simplex, a marine planktonic, bloom-forming dinoflagellate (accession number AY686651), was used as an outgroup.

Sequences were aligned using CLUSTAL-W 1.83 (Thompson et al. 1997) and cladistic analyses, using distance neighbour joining, were conducted on aligned data sets with the PAUP 4.0 beta 8 software (Swofford 2002). The optimal criterion for neighbourjoining trees was set as distance (minimum evolution) with distance measured using the HKY85 parameter model. Bootstrap re-sampling was conducted for 100 replicates to assess relative branch support.

Thermal stress experiment. Stylophora pistillata colonies growing naturally at $30 \mathrm{~m}$ and at $2 \mathrm{~m}$ depth beneath the IUI pier (i.e. corals photoacclimated to relatively low photosynthetically active radiation, PAR) were collected during December 2006 (n = 4 at each depth). The colonies chosen had been previously marked and their respective zooxanthellae genotyped (mentioned above). The downwelling irradiances at the collection sites were measured from 10:00 to 10:15 h with the Diving-PAM's (Walz; see below) quantum sensor, which had previously been calibrated against an LI-189 quantum sensor connected to an LI1000 data logger (Li-Cor; see Winters et al. 2003) and were 30 and $40 \mu \mathrm{mol}$ photons $\mathrm{m}^{-2} \mathrm{~s}^{-1}$ at depths of $30 \mathrm{~m}$ and $2 \mathrm{~m}$ under the pier, respectively, as compared to $400 \mu \mathrm{mol}$ photons $\mathrm{m}^{-2} \mathrm{~s}^{-1}$ at $2 \mathrm{~m}$ beside the pier. Each colony was broken into 2 fragments, which were kept in an upright position by gently inserting them into plastic pegs submerged in $3.4 \mathrm{l}$ plastic outdoor aquaria. All aquaria (16 in total) were filled with seawater, equipped with a small submerged water pump and kept at a daily average water temperature of $23^{\circ} \mathrm{C}$ $\left( \pm 0.5^{\circ} \mathrm{C} \mathrm{SE}\right)$ measured using HOBO Water Temp Pro data loggers (Onset Computers). Corals were shaded using 2 black shade nets (95\% light reduction) producing a light environment with similar PAR values to those experienced at the corals' growing site (midday irradiance of $60 \mu \mathrm{mol}$ photons $\mathrm{m}^{-2} \mathrm{~s}^{-1}$ measured under the nets using an LI-190 2 quantum sensor connected to an LI-1400 data logger, Li-Cor, USA). Following $24 \mathrm{~h}$, the temperature in half of the aquaria was increased using submersible water heaters to a daily average temperature of $31^{\circ} \mathrm{C}\left( \pm 0.8^{\circ} \mathrm{C} \mathrm{SE}\right)$.

Using the Diving-PAM (Walz), $F_{\mathrm{v}} / F_{\mathrm{m}}$ was measured for all corals at times 0 and 24 and $48 \mathrm{~h}$ after the above thermal treatment. Measurements were done $1 \mathrm{~h}$ after sunset; this period of darkness was previously found to be sufficient to maximise the frequency of open reaction centres in photosystem II (Winters et al. 2003). After $48 \mathrm{~h}$, both the shallow- and deep-derived corals 
in the low-light/low-temperature treatment were frozen and kept at $-70^{\circ} \mathrm{C}$ for later verification of their genetic type of symbionts residing within them.

Statistical analyses. Data were analysed using STATISTICA 6.0 (Statsoft). The effect of time on zooxanthella density (i.e. temporal photoacclimation) was measured using repeated measures analysis of variance (ANOVA) since each colony was measured repeatedly each month, with 12 levels (months) and 4 to 6 colonies sampled every month. A similar analysis was made for the effect of time on chlorophyll content per cell and on chlorophyll density. The effect of collection depth on zooxanthella density (i.e. spatial photoadaptation) was tested using a 1-way ANOVA with depth (4 levels) as a categorical predictor (factor) and zooxanthella density measured per coral ( $\mathrm{n}=6$ to 7 for each depth) as a dependent factor. A similar analysis was made for the effect of depth on chlorophyll content per cell and on chlorophyll density. ANOVAs were performed only after verifying homogeneity of variances. Following significant ANOVA results, differences between the treatments were tested using Tukey HSD post hoc tests.

Linear correlation coefficients (r) were used to evaluate the relationships between the different zooxanthella biomass parameters and the environmental parameters measured. The Bonferroni correction was applied to this data set with significant correlations reported if $\mathrm{p}<0.0024$ (the results of alpha [0.05] corrected for 3 dependent $\times 7$ independent parameters tested). For the histological examination, results taken from different histological sections belonging to the same coral were pooled $(n=4$ different colonies sampled at each depth and light treatment, $\mathrm{n}=5$ colonies sampled repetitively in summer and winter) and $t$-tests for independent samples by groups were performed with the distances/sizes of zooxanthellae as the dependent variable and depth/season/light treatment used as a grouping variable.

The effects of temperature $\left(23^{\circ} \mathrm{C}\right.$ and $\left.31^{\circ} \mathrm{C}\right)$ and source of colonies (shallow clade A colonies and deep clade $\mathrm{C}$ colonies) on $F_{\mathrm{v}} / F_{\mathrm{m}}$ values were determined using repeated measures 2-way ANOVA, with time $(0,24$ and $48 \mathrm{~h})$ as the repeated measure and 3 to 4 colonies sampled at each time point. ANOVA was performed only after verifying homogeneity of variances. Significant differences among treatment groups were determined post hoc using Tukey HSD tests.

\section{RESULTS}

Maximal diurnal surface radiation ranged seasonally from $\sim 550 \mathrm{~W} \mathrm{~m}^{-2}$ during the winter (November 2004 to January 2005) to $\sim 950 \mathrm{~W} \mathrm{~m}^{-2}$ during the spring/early summer (April to June 2005; Fig. 1a). Maximal diel seawater temperatures ranged from $21.6^{\circ} \mathrm{C}$ during the spring (March to April 2005) to $27.3^{\circ} \mathrm{C}$ in the summer (July to August 2005), thus lagging behind those of maximal irradiance by $\sim 3$ mo. Indeed, there was no relationship between maximal diurnal surface radiation and maximal diel seawater temperature $(\mathrm{r}=0.07$, $\mathrm{p}>0.05)$. Spring minimal water temperatures coincided with an increase in nitrogen, with the highest levels of $\mathrm{NO}_{3}{ }^{-}$measured during January 2005 and the highest levels of $\mathrm{NO}_{2}^{-}$measured during March 2005 (Fig. 1b).

Chlorophyll densities changed significantly over time (repeated measures ANOVA, $F_{11,33}=10.2, \mathrm{p}<$ 0.01; Fig. 2a) and with depth (Fig. 2d; ANOVA $F_{3,23}=$ 7.24, $\mathrm{p}<0.01$ followed by Tukey HSD post hoc test). For shallow corals sampled throughout the year, chlorophyll densities during winter months (November 2004 to January 2005) were 3 times higher than those measured during the summer months (June to August
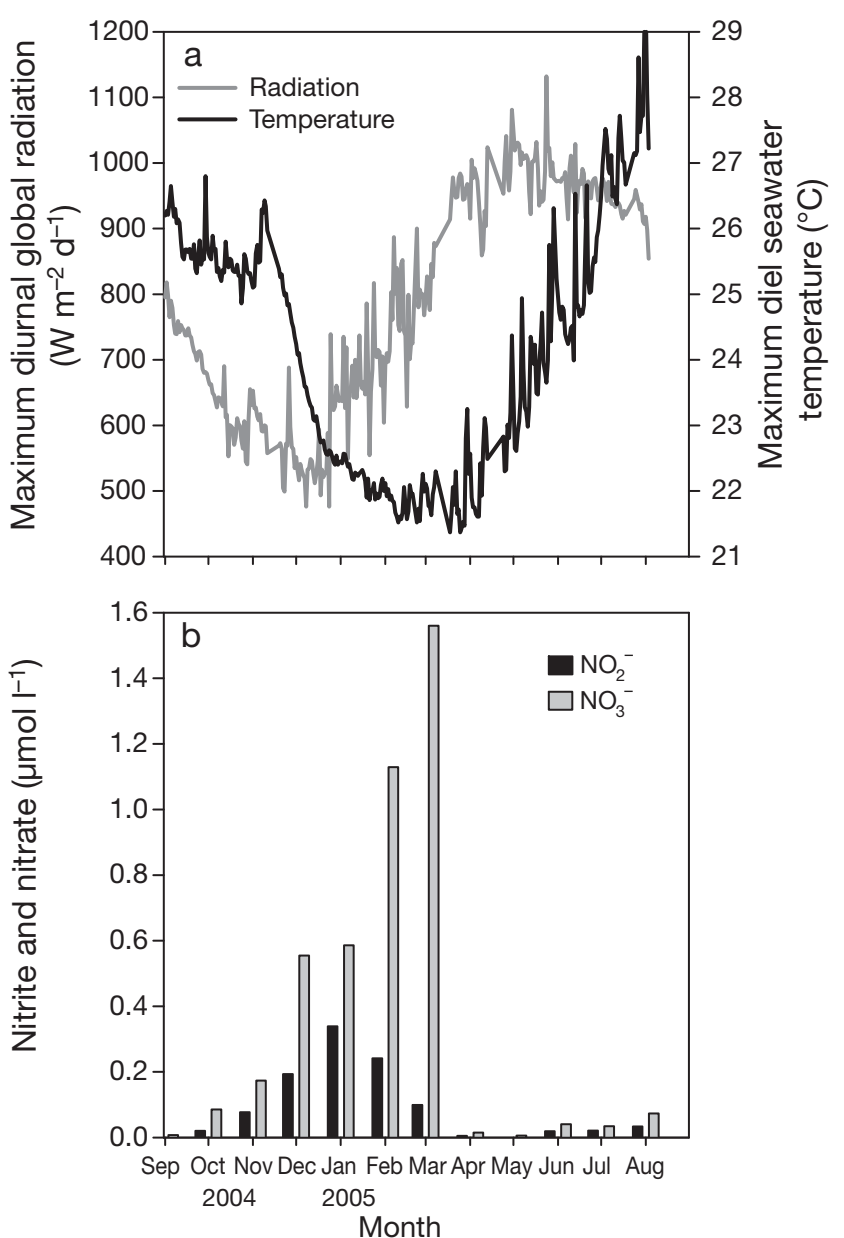

Fig. 1. Seasonal variations in (a) maximum diurnal global radiation and maximum diel seawater temperature (from Winters et al. 2006) and (b) seawater concentrations of nitrite $\left(\mathrm{NO}_{2}^{-}\right)$and nitrate $\left(\mathrm{NO}_{3}^{-}\right)$ 
2005; Tukey HSD post hoc test, p < 0.05). Chlorophyll densities of colonies growing at 20 and $10 \mathrm{~m}$ depth were 2.4 to 2.9 and 1.3 to 1.6 times higher than found in colonies growing at 1 and $5 \mathrm{~m}$ depth, respectively (Fig. 2d). Thus, corals exposed to low-light environments, caused by increased depth or that experienced by shallow-growing corals during the low-irradiance winter months, had increased their chlorophyll densities. However, further analysis showed differences in the mechanism that caused these increases.

Temporal photoacclimation involved significant changes over time in zooxanthella density (repeated measures ANOVA, $F_{11,33}=6.539, \mathrm{p}<0.01$, followed by
Tukey HSD post hoc test, $\mathrm{p}<0.05$; Fig. 2b). Highest algal cell densities were measured during periods of high $\mathrm{NO}_{3}^{-}$levels (March 2005) or low irradiance (December 2004 to January 2005) compared to summer levels during which cell density was $~ 50 \%$ and $\sim 30 \%$ of those measured during the winter and early spring, respectively. Winter-time zooxanthella chlorophyll content was $\sim 40 \%$ higher than that of the same corals in the summer (repeated measures ANOVA, $F_{11,33}=4.615, \mathrm{p}<0.01$, followed by Tukey HSD post hoc test, $\mathrm{p}<0.05$; Fig. 2c).

In comparison with temporal changes, zooxanthella density of Stylophora pistillata colonies did not change
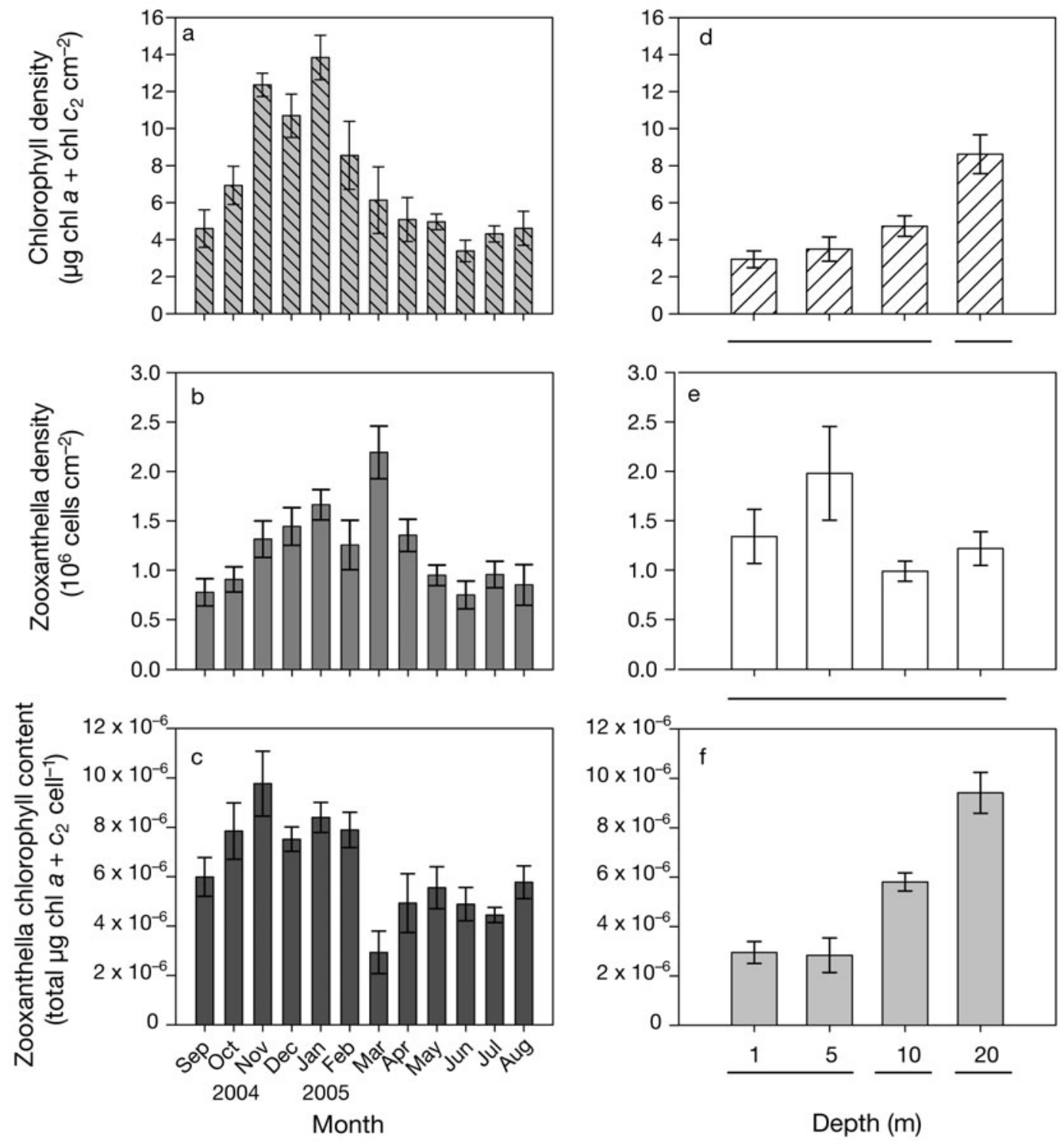

Fig. 2. Stylophora pistillata. Chlorophyll density (a,d), zooxanthella density $(b, e)$ and zooxanthella chlorophyll content (c,f) for colonies growing at $5 \mathrm{~m}$ and sampled over time $(\mathrm{a}-\mathrm{c}, \mathrm{n}=4$ to 6 colonies sampled each month, \pm SE) and for colonies sampled within the same week but growing at 1 to $20 \mathrm{~m}$ depth $(\mathrm{d}-\mathrm{f}, \mathrm{n}=6$ to 7 at each depth; total $\mathrm{n}=27, \pm$ SE). Horizontal lines on righthand panels indicate results that are not significantly different ( $p>0.05$, ANOVA followed by Tukey HSD post hoc tests) 
significantly with depth (Fig. 2e; ANOVA $F_{3,23}=2.25$, $\mathrm{p}>0.05)$. However, zooxanthellae within deeper colonies had significantly higher chlorophyll contents compared to their shallower counterparts (spatial photoacclimation, Fig. 2f; ANOVA $F_{3,23}=17.93, p<0.01$; followed by Tukey HSD post hoc test). Thus, the significant increase in chlorophyll density in deeper corals (Fig. 2d; ANOVA $F_{3,23}=7.24, \mathrm{p}<0.01$ followed by Tukey HSD post hoc test), which could have been due to increased zooxanthella density and/or increased algal chlorophyll content, was, in this case, due to the sole contribution of increased algal chlorophyll content.

While no significant relationship was found between seasonal changes in zooxanthella density and diurnal radiation, irradiance (and especially average irradiance) did play an important negative role in determining zooxanthella chlorophyll content $(\mathrm{r}=0.81, \mathrm{p}<$ $0.0024)$ and, thus, chlorophyll density ( $r=0.85, \mathrm{p}<$ 0.0024 ; Table 1). Although there was a negative relationship between cell density and maximal and average water temperatures $(\mathrm{r}=-0.7361, \mathrm{p}<0.01$ and $\mathrm{r}=$ $-0.7102, \mathrm{p}<0.01$, respectively), neither was significant after applying the relatively conserved Bonferroni correction. Water temperature showed no relationship with zooxanthella chlorophyll content (Table 1). In addition, while both light and temperature were found to have negative relationships with zooxanthella chlorophyll content and cell density, nitrogen, and especially $\mathrm{NO}_{3}{ }^{-}$, was found to have a positive relationship with the amount of cells hosted by the coral ( $\mathrm{r}=$ $0.81, \mathrm{p}<0.0024)$. Surprisingly, the high levels of nitrogen that were associated with increases in cell density were not associated with changes in zooxanthella chlorophyll content (Table 1).

Comparisons of solar irradiances derived from the CAYAN Si model of several reefs around the world

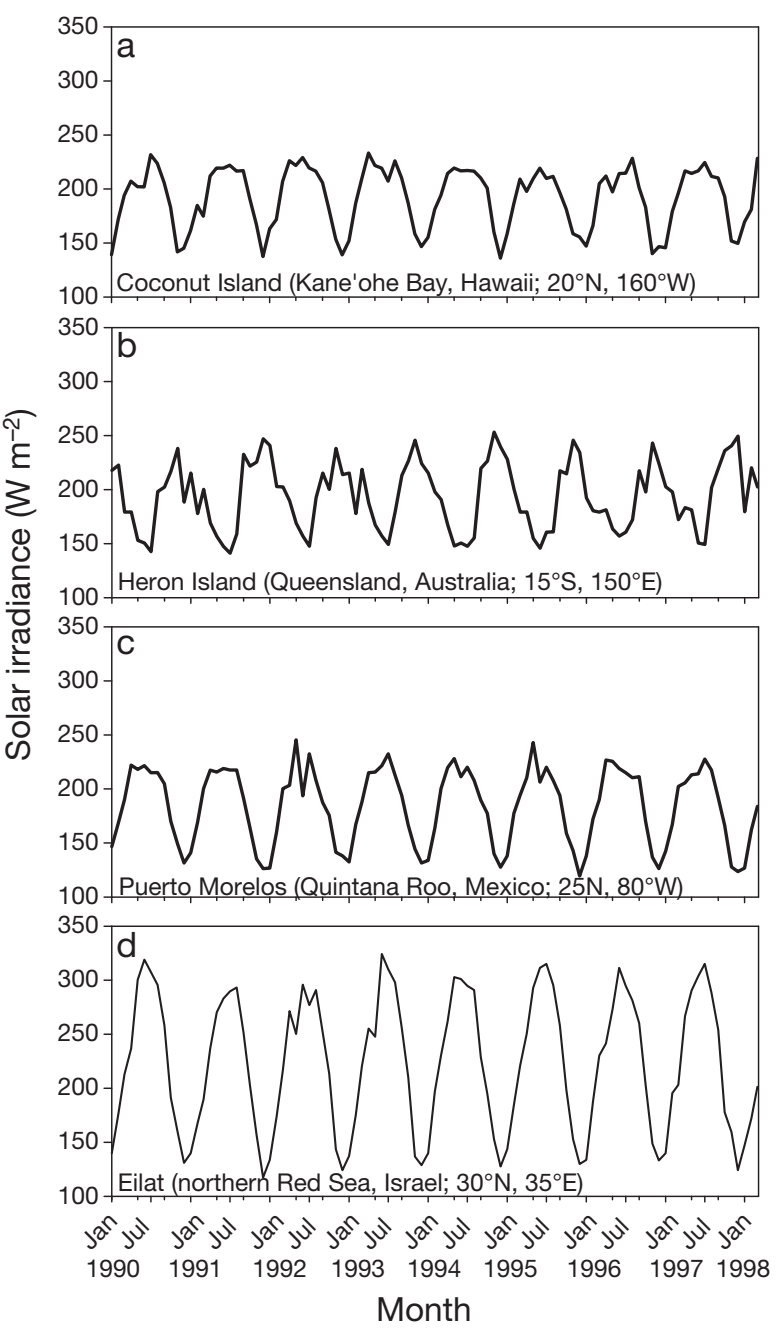

Fig. 3. Comparison of solar irradiance $\left(\mathrm{W} \mathrm{m}^{-2}\right)$ in the proximity of several coral reefs based on the CAYAN Si model (Cayan 1992; http://ingrid.ldeo.columbia.edu/SOURCES/.CAYAN/.Si/)
Table 1. Linear correlation coefficients (r) for values of monthly zooxanthella parameters ( $\mathrm{n}=4$ to 6 colonies sampled each month) compared to monthly averages of diel maximum and average radiation, diel maximum and average water temperature and monthly surface seawater concentrations of nitrite $\left(\mathrm{NO}_{2}{ }^{-}\right)$, nitrate $\left(\mathrm{NO}_{3}{ }^{-}\right)$and total oxidised nitrogen (TON). ${ }^{*} \mathrm{p}<0.0024$ (significance after applying the Bonferroni correction, see text for details)

\begin{tabular}{|lccc|}
\hline & $\begin{array}{c}\text { Zooxanthella } \\
\text { density } \\
(\text { cells cm }\end{array}$ & $\begin{array}{c}\text { Chlorophyll } \\
\text { content } \\
\left(\mu \mathrm{g} \mathrm{chl} \mathrm{a}+\mathrm{C}_{2}\right. \\
\text { per algal cell) }\end{array}$ & $\begin{array}{c}\text { Chlorophyll } \\
\text { density } \\
\left(\left[\mu \mathrm{g} \mathrm{chl} \mathrm{a}+\mathrm{C}_{2}\right]\right. \\
\left.\mathrm{cm}^{-2}\right)\end{array}$ \\
\hline Maximum radiation & -0.14 & $-0.83^{*}$ & -0.76 \\
Average radiation & -0.34 & $-0.81^{*}$ & $-0.85^{*}$ \\
Maximum temperature & -0.73 & $>-0.1$ & -0.42 \\
Average temperature & -0.71 & $>0.1$ & -0.31 \\
$\mathrm{NO}_{2}^{-}$ & 0.54 & 0.49 & $0.79^{*}$ \\
$\mathrm{NO}_{3}^{-}$ & $0.81^{*}$ & -0.10 & 0.32 \\
$\mathrm{TON}^{*}$ & $0.81^{*}$ & $>0.01$ & 0.43 \\
\hline
\end{tabular}

(Fig. 3) for the years 1990 to 1998 revealed that corals in Eilat are exposed to some $40 \%$ more surface solar irradiance than their counterparts elsewhere.

Histological examination showed that shallow-growing colonies were characterised by a relatively thick ectoderm that was separated from the endoderm by a distinct mesoglea, compared to deeper-growing colonies that were characterised by a much thinner ectoderm and a mesoglea that was hardly noticeable (Fig. 4). Measuring distances within these slides revealed that zooxanthella cells within Stylophora pistillata colonies growing at $2 \mathrm{~m}$ depth were on average $22 \%$ 

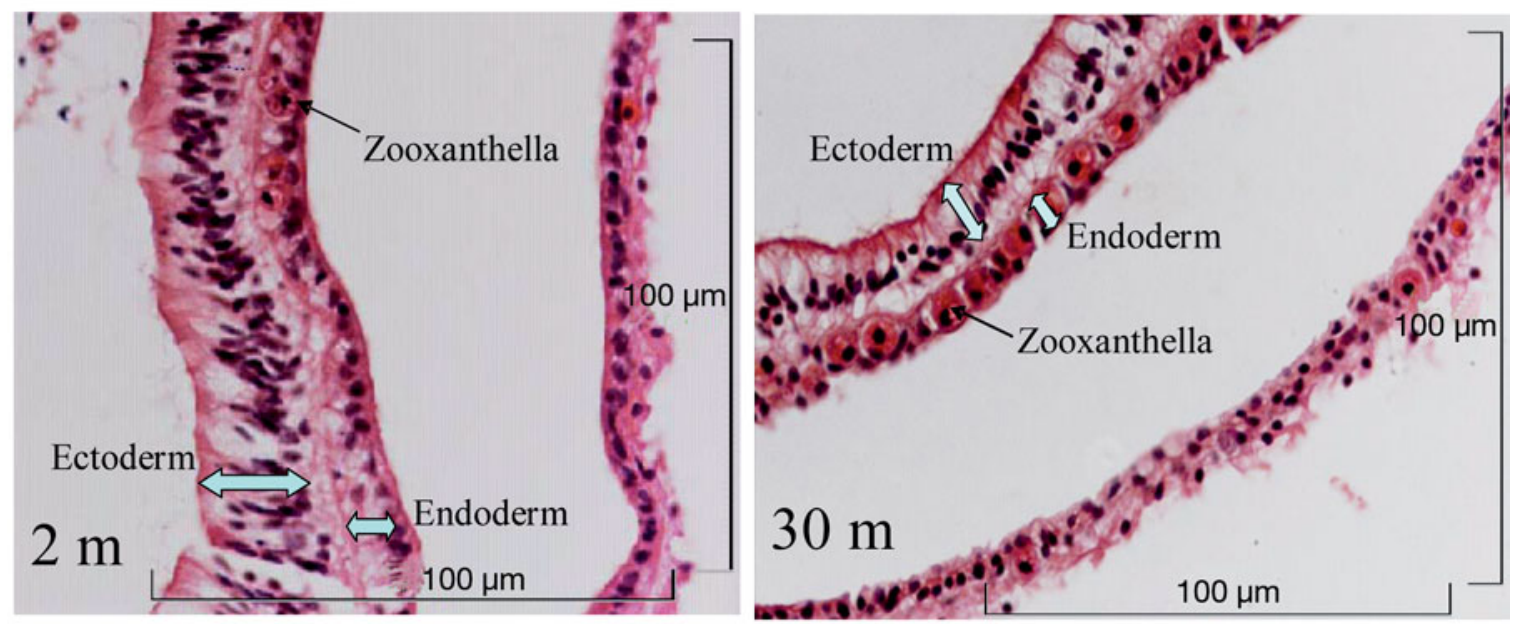

Fig. 4. Stylophora pistillata. Photomicrographs of histological sections from colonies from depths of $2 \mathrm{~m}$ (left) and $30 \mathrm{~m}$ (right) showing zooxanthellae, endoderm and ectoderm. Scale bars are $100 \mu \mathrm{m}$

deeper inside their host tissue $(t$-test, $\mathrm{p}<0.05$; in total, 48 and 61 cells were measured from 4 colonies growing at 2 and $30 \mathrm{~m}$, respectively; Fig. 5a) compared to the deeper-growing corals. In addition, zooxanthella within colonies growing at $2 \mathrm{~m}$ depth were $20 \%$ smaller in diameter ( $t$-test, $\mathrm{p}<0.05$; in total, 29 and 44 cells were measured from 4 colonies growing 2 and
$30 \mathrm{~m}$ respectively; Fig. 5d) than cells within colonies growing in deeper waters. In addition to such spatial photoacclimation, analysis of histological slides prepared from the same colonies sampled during summer and winter demonstrated temporal photoacclimation. Shallow-growing corals sampled during the summer hosted deeper ( $t$-test, $\mathrm{p}<0.01$; Fig. 5b) and smaller
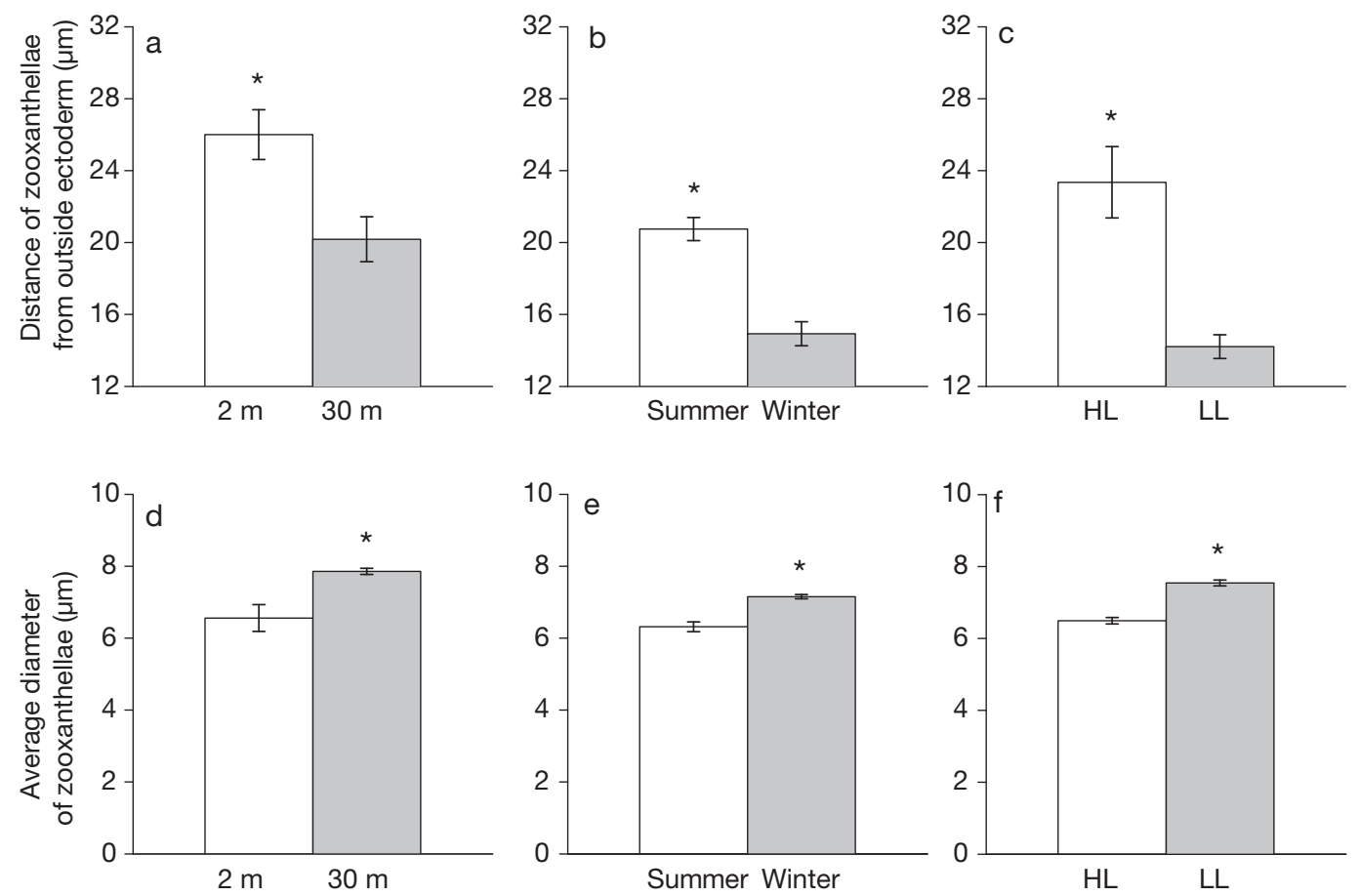

Fig. 5. Stylophora pistillata. Distance of zooxanthella cells from the outside of the ectoderm (a-c) and average diameter of zooxanthellae (d-f) measured for colonies growing naturally at depths of 2 and $30 \mathrm{~m}(\mathrm{a}, \mathrm{d})(\mathrm{n}=4, \pm \mathrm{SE})$, colonies growing at the same depth $(5 \mathrm{~m})$ but sampled during the summer (June 2007) and winter (December 2006) (b,e) $(\mathrm{n}=5, \pm \mathrm{SE})$ and colonies growing under controlled conditions of high (HL) and low light (LL; corals growing under 50 and $85 \%$ shade, respectively); $(\mathrm{c}, \mathrm{f})(\mathrm{n}=4, \pm \mathrm{SE})$. All measurements were made using UTHSCSA Image tool 3.0. *Significantly higher values $(t$-test, $\mathrm{p}<0.05$; see text for details) 


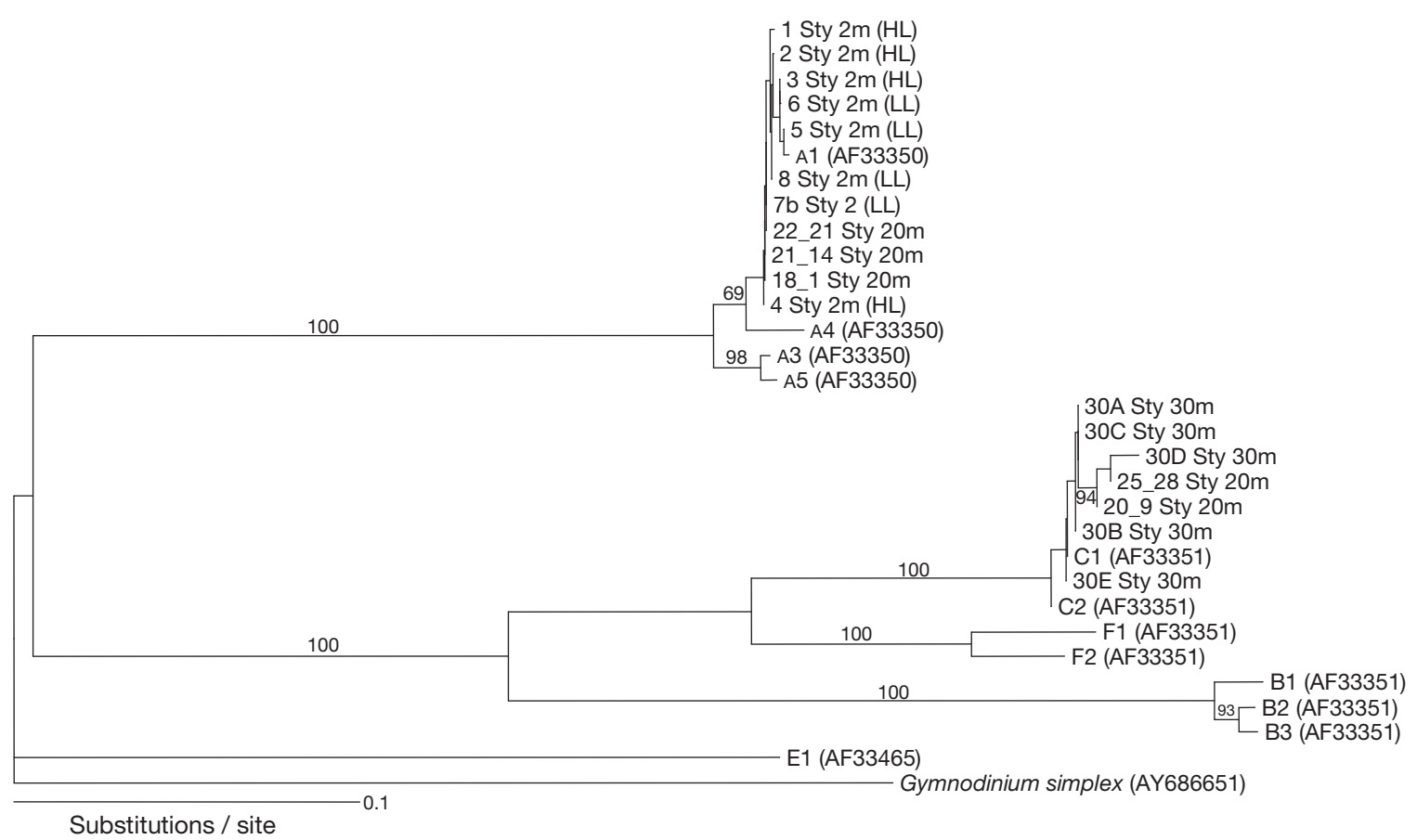

Fig. 6. Phylogenetic relationship (distance neighbour joining) derived from ITS-2 sequences of zooxanthellae isolated from Stylophora pistillata growing at different depths $(2,20,30 \mathrm{~m})$ and light conditions: $2 \mathrm{~m}$ high light (HL) and low light (LL). Also included are ITS-2 sequences derived from LaJeunesse (2001; see text for details). Gymnodinium simplex, GenBank accession number AY829531, was used as an outgroup. Bootstrap support values are given as percentages of 100 replicates

zooxanthellae ( $t$-test, $\mathrm{p}<0.01)$ compared to repeated tissue samples taken from the same colonies during the winter. Similar morphological acclimations to high/low-light environments were found in zooxanthellae from corals experimentally exposed to high- and lowlight conditions ( $t$-tests, $\mathrm{p}<0.01$ for both size and depth of zooxanthellae; Fig. $5 \mathrm{c}, \mathrm{f}$ ).

Use of ITS-2 as a genetic marker revealed that shallow-growing colonies harboured zooxanthellae that clustered with Symbiodinium clade A, while deeper growing colonies harboured clade $\mathrm{C}$ symbionts (Fig. 6). The analysis also showed that there probably is a gradient, with some colonies growing at the intermediate depths $(20 \mathrm{~m})$ hosting clade A and others clade C. Interestingly, for shallow corals growing at $2 \mathrm{~m}$ depth, the light environment from which the corals were collected did not have an effect on the zooxanthella genetic identity; colonies collected at both lowlight environments (i.e. at $2 \mathrm{~m}$ under the IUI pier with winter PAR values of $\sim 40 \mu \mathrm{mol}$ photons $\mathrm{m}^{-2} \mathrm{~s}^{-1}$ ) or at very high light conditions (at $2 \mathrm{~m}$ beside the pier but with 10 times more light) always hosted clade A. Thus, while corals growing at $2 \mathrm{~m}$ under the pier and at $30 \mathrm{~m}$ (PAR of $\sim 30 \mu \mathrm{mol}$ photons $\mathrm{m}^{-2} \mathrm{~s}^{-1}$ ) were accustomed to very similar PAR doses, they hosted different genetic types of zooxanthellae.

In the water table experiment, at time 0 (the onset of thermal stress) no significant differences were found between $F_{\mathrm{v}} / F_{\mathrm{m}}$ values of deeper colonies hosting clade $\mathrm{C}$ and values of shallow waters colonies hosting clade $\mathrm{A}$ ( $p>0.05$, Tukey HSD post hoc tests following ANOVA; Fig. 7). Exposure of Stylophora pistillata colonies to

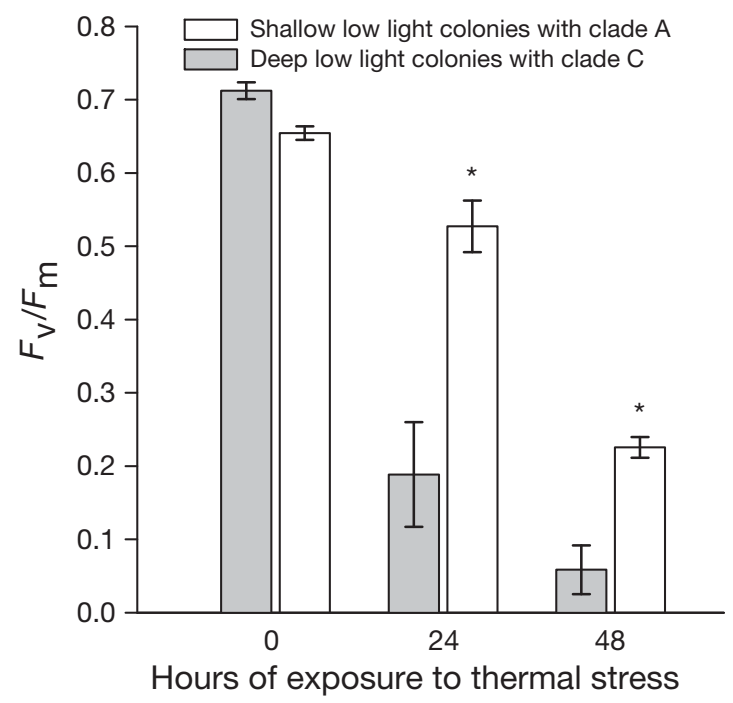

Fig. 7. Stylophora pistillata. $F_{\mathrm{v}} / F_{\mathrm{m}}$ for low-light colonies collected from $2 \mathrm{~m}$ (under the IUI pier) and $30 \mathrm{~m} \mathrm{(n=3}$ to 4 at each depth), containing clade $\mathrm{A}$ and clade $\mathrm{C}$ symbionts, respectively, exposed to 0,24 and $48 \mathrm{~h}$ of thermal stress $\left(31^{\circ} \mathrm{C}\right)$ under low-light conditions (95\% shade, see text for details). ${ }^{*}$ Significantly higher values $(\mathrm{p}<0.05$, Tukey HSD post hoc tests following ANOVA; see text for details) 
Table 2. Repeated measures 2-way ANOVA for the effects of temperature $\left(23\right.$ and $31^{\circ} \mathrm{C}$ ) and collection depth of colonies ( $2 \mathrm{~m}$ colonies found to host clade $\mathrm{A}$ and $30 \mathrm{~m}$ colonies found to host clade C) on $F_{\mathrm{v}} / F_{\mathrm{m}}$ values, with time $(0,24,48 \mathrm{~h})$ as the repeated measure and 3 to 4 colonies sampled at each time point. ${ }^{* *} \mathrm{p}<0.01,{ }^{* * *} \mathrm{p}<0.001$

\begin{tabular}{|lcccc|}
\hline Source of variation & df & Mean square & $F$ & $\mathrm{p}$ \\
\hline Temperature & 1 & 0.83132 & 322.065 & ${ }^{* * *}$ \\
Depth & 1 & 0.03152 & 12.590 & ${ }^{* *}$ \\
Temperature $\times$ depth & 1 & 0.08586 & 34.295 & ${ }^{* * *}$ \\
Error & 10 & 0.00250 & & \\
Time & 2 & 0.31204 & 91.034 & ${ }^{* * *}$ \\
Time $\times$ temperature & 2 & 0.21377 & 62.365 & ${ }^{* * *}$ \\
Time $\times$ depth & 2 & 0.03901 & 11.382 & ${ }^{* * *}$ \\
$\begin{array}{l}\text { Time } \times \text { temperature } \times \\
\text { depth }\end{array}$ & 2 & 0.03473 & 10.133 & ${ }^{* * *}$ \\
Error & 20 & 0.00343 & & \\
\hline
\end{tabular}

$31^{\circ} \mathrm{C}$ caused a significant decrease in $F_{\mathrm{v}} / F_{\mathrm{m}}$ values over time, both for clade $\mathrm{A}$ and clade $\mathrm{C}$ colonies. $F_{\mathrm{v}} / F_{\mathrm{m}}$ values of colonies hosting clade A were 20 and $65 \%$ lower compared to values at time 0 after 24 and $48 \mathrm{~h}$, respectively. However, they were significantly lower in colonies hosting clade C, dropping 73 and $91 \%$ (compared to values at time 0 ) after 24 and $48 \mathrm{~h}$, respectively (Fig. 7, Table 2). $F_{\mathrm{v}} / F_{\mathrm{m}}$ values for corals exposed to the control temperature $\left(23^{\circ} \mathrm{C}\right.$, ambient seawater temperature at the time of collection), did not change significantly throughout time for both shallow colonies with clade A and for deep colonies with clade $\mathrm{C}(\mathrm{p}>0.05$, Tukey HSD post hoc tests following ANOVA; Table 2).

DNA typing of zooxanthella ITS-2 from the lowlight/low-temperature corals verified that all corals from under the pier hosted clade $A$, while those from $30 \mathrm{~m}$ depth hosted clade $\mathrm{C}$ (results not shown).

\section{DISCUSSION}

This work identifies some of the mechanisms by which Stylophora pistillata acclimates to changing irradiances. These include changes in algal chlorophyll content with depth and mainly zooxanthella density with season, both resulting in increased chlorophyll density. These 2 mechanisms might involve different costs and benefits to both the algae and the host. Hosting more algae in deeper corals would mean that the penetration of light to a specific algal cell would be even further reduced by self-shading ('the packaging effect', Berner et al. 1989). Thus, the most efficient way of increasing the ability to capture light in this case would be an increase of light-capturing antenna complexes, resulting in an increase in zooxanthella chlorophyll content and, possibly, larger algal cells.
The increases in algal chlorophyll content with increased depth concur with other zooxanthellarelated research on Stylophora pistillata in the northern Red Sea (Falkowski \& Dubinsky 1981, Mass et al. 2007). Although our results show that the increase in depth did not cause significant changes in zooxanthella density (also shown by Falkowski \& Dubinsky 1981 and Mass et al. 2007), both Dustan (1982, for Montastrea annularis in the Caribbean) and Titlyanov et al. (2001, for S. pistillata in Okinawa, Japan) documented such changes as a result of acclimation to increased depth accompanied by low irradiances. Thus, it is possible that different species, and/or similar species growing in different regions, differ in their ways of increasing chlorophyll density as a means of acclimating to low-light environments. While temporal changes in zooxanthella biomass parameters have been studied before, most of those studies only followed changes in zooxanthella density and did not include information about algal chlorophyll content and/or chlorophyll density (Fagoonee et al. 1999, Warner et al. 2002), both of which affect the lightcapturing ability of the coral. In addition, some studies have related the seasonal changes in zooxanthella density to one environmental parameter, i.e. either temperature (Fitt et al. 2000, Shenkar et al. 2006) or $\mathrm{NO}_{3}{ }^{-}$(Fagoonee et al. 1999). The results presented here demonstrate a more complex situation, with different algal mechanisms being affected by different environmental parameters. While zooxanthella density was negatively affected by an increase in water temperature (as was the case in Shenkar et al. 2006), it was positively affected by levels of nitrogen, and especially $\mathrm{NO}_{3}{ }^{-}$. This positive effect concurs both with previous field studies (Fagoonee et al. 1999) and laboratorybased nitrogen enrichments (Marubini \& Davies 1996), further suggesting that growth of zooxanthellae in shallow waters is nitrogen-limited. Considering that both water temperature and nutrient levels are expected to increase under global change, particularly in coastal environments (Harley et al. 2006), these results emphasise the importance of future assessments taking into account the combination of these parameters.

Another acclimation to irradiance was found in the size and location of zooxanthellae within the host tissue; zooxanthellae from high-light environments were smaller and were located deeper within the animal tissue than those within colonies growing in low-light environments. The latter finding indicates a hostmediated mechanism of shading the algae from high irradiances (whether PAR or ultraviolet radiation). While such a mechanism has thus far not been described for scleractinian corals, it has been found both in the shallow-growing Symbiodinium-contain- 
ing zoanthid Palythoa caribaeorum (LaJeunesse 2002) and in the corallimorph Rhodactis rhodostoma (Kuguru et al. 2007).

Within the northern Red Sea, shallow-growing Stylophora pistillata colonies hosting clade A zooxanthellae differ from most other shallow hermatypic and soft corals sampled in the region, which host clade C (Barneah et al. 2004, Karako-Lampert et al. 2004). These colonies also differ from $S$. pistillata sampled at similar depths in the Great Barrier Reef (GBR), which contain the dominant clade C type (LaJeunesse et al. 2003). In the northern Gulf of Aqaba, not only is S. pistillata among the most dominant coral species (Loya 1972), but it is also continuously present between 2 and $65 \mathrm{~m}$ depth (Loya 1976, Mass et al. 2007). The ability of some coral species to grow along large depth gradients has been related to the lack of host-symbiont specificity (Iglesias-Prieto et al. 2004), enabling the coral animal to host genetically different types of algal symbionts photoadapted to different light environments (Dustan 1982, Rowan \& Knowlton 1995). Indeed, the finding that Montastraea annularis populations in the Caribbean were dominated by clade A and some B in shallow waters but shifted to hosting only clade $\mathrm{C}$ in deeper waters (9 to $14 \mathrm{~m}$ ) was hypothesised to be due to differential light adaptation of the different clades (Rowan \& Knowlton 1995). Focusing on another dominant Caribbean coral, Acropora cervicornis, Baker et al. (1997) attributed the relatively wide depth distribution of this species to its ability to switch from clade Ahosting colonies in shallow waters ( 0 to $9 \mathrm{~m}$ ) to clade Chosting colonies in deeper waters (12 to $20 \mathrm{~m}$ ). These authors concluded that hosting different algal symbionts enabled the coral host to 'live competitively in different photic habitats'.

Similar to those findings, our genetic analysis demonstrates that Stylophora pistillata shifts from hosting clade $\mathrm{A}$ in shallow waters to clade $\mathrm{C}$ in deeper waters. This could indicate that $S$. pistillata in the northern Red Sea lacks host-symbiont specificity, and might explain the success of this 'opportunistic' species in this region in a depth range of 2 to $65 \mathrm{~m}$ (Mass et al. 2007). However, the fact that both high-light (growing at $2 \mathrm{~m}$ ) and shallow low-light colonies (growing at $2 \mathrm{~m}$ under the IUI pier, which experience very similar irradiances as colonies growing at $30 \mathrm{~m}$ ) were found to host clade $\mathrm{A}$, indicates that it is the bathymetric location (and not irradiance per se) that determines the zooxanthella clade of the host. Future translocations of corals from deep to shallow and vice versa, with and without cut-off filters, could help in elucidating this host-symbiont depth-specificity issue.

The short-term thermal stress experiment presented here showed differential thermal stress responses between in hospite clades $\mathrm{A}$ and $\mathrm{C}$, with the latter being more thermally sensitive. Although physiological comparisons with genetically different in hospite zooxanthellae have been limited (Iglesias-Prieto et al. 2004, Rowan 2004, Warner et al. 2006, this study), clade $C$ appears to be more thermally sensitive than clades D (Rowan 2004, Berkelmans \& van Oppen 2006) and B (Warner et al. 2006). The fact that clade C seems to be more thermally sensitive than some other clades at the same time as being dominant in most corals in Eilat (Barneah et al. 2004, Karako-Lampert et al. 2004) as well as in the southern Red Sea (Baker et al. 2004), could be related to the relatively deep, and thus cool, waters in this region where bleaching events have not yet been reported (Karako-Lampert et al. 2004).

While temporal effects of light on pigment density in corals has been largely overlooked in favour of temperature (Hoegh-Guldberg \& Smith 1989, Brown et al. 1995, Warner et al. 2002) and nutrients (Marubini \& Davies 1996, Fagoonee et al. 1999), our results confirm our earlier suggestion that light is an important regulating force in temporal photophysiological acclimations of corals (Winters et al. 2006). Thus, in Winters et al. (2006), seasonal changes in irradiance caused reciprocal changes in $F_{\mathrm{v}} / F_{\mathrm{m}}$, and in the present work, we show that chlorophyll density and algal chlorophyll content also change reciprocally with irradiance. The fact that shallow coral reefs in this region may be exposed to especially high irradiances as compared to many other reefs, causing both dynamic and longlasting chronic photoinhibition (Winters et al. 2003), could be the reason that in this region light is the main driving force behind the observed seasonal photophysiological changes.

In addition to being an important tool for photophysiological studies, measurements of zooxanthella parameters performed over time have several other implications. Since changes in zooxanthella parameters have been shown in some cases to indicate coral stress (Hoegh-Guldberg \& Smith 1989, Warner et al. 2002), following temporal changes in such parameters could also be useful in order to monitor coral health (Jones 1997) and, thus, help to estimate the severity of forthcoming bleaching events and, accordingly, also rates of recovery. In addition, measurements of zooxanthella parameters accompanied by environmental data on e.g. irradiance, temperature and nutrients will make it possible to compare the status of corals (preferably the same species) growing at different locations around the world. Although light was demonstrated in this study to be the main driving force behind the observed seasonal changes in chlorophyll density for Stylophora pistillata growing in the northern Red Sea (see also Winters et al. 2006), the same species growing for example in the Indian Ocean or in the GBR might be more sensitive to temperature. Such a comparison 
would also reveal if the same species growing at different locations has adapted and/or acclimated to the local conditions, resulting in different threshold and tolerance limits to certain environmental parameters.

Taken together, the changes in (1) algal density and/or chlorophyll content, (2) size and location of the algal symbiont, and possibly (3) the actual genetic type of algae hosted, are indeed evidence of different mechanisms that help adjust the light-capturing abilities of Stylophora pistillata zooxanthellae to spatial and temporal changes in irradiance. These mechanisms might thus at least partly explain the success of this opportunistic species in its ability to grow along the wide depth and light gradients where it is found.

Acknowledgements. We thank the Inter-University Institute for Marine Sciences at Eilat for their help and support. We thank The Israel National Monitoring Program for the nutrient data. We thank Sigrid Penno and Yoni Sharon, for help with the phylogenies and bleaching experiment, respectively. Funding from the Rufford Foundation for Nature Conservation and PADI Foundation to GW and from the Israel Science Foundation to YL are greatly acknowledged.

\section{LITERATURE CITED}

Anthony KRN, Hoogenboom MO, Connolly SR (2005) Adaptive variation in coral geometry and the optimization of internal colony light climates. Funct Ecol 19:17-26

Baker AC, Rowan R, Knowlton N (1997) Symbiosis ecology of 2 Caribbean acroporid corals. Proc 8th Int Coral Reef Symp, Panama 2:1295-1300

Baker AC, Starger CJ, McClanahan TR, Glynn PW (2004) Corals' adaptive response to climate change. Nature 430:741

Barneah O, Weis VM, Perez S, Benayahu Y (2004) Diversity of dinoflagellate symbionts in Red Sea soft corals: mode of symbiont acquisition matters. Mar Ecol Prog Ser 275: 89-95

Berkelmans R, van Oppen MJH (2006) The role of zooxanthellae in the thermal tolerance of corals: a 'nugget of hope' for coral reefs in an era of climate change. Proc $\mathrm{R}$ Soc Lond B Biol Sci 273:2305-2312

Berner T, Dubinsky Z, Wyman K, Falkowski PG (1989) Photoadaption and the 'package' effect in Dunatiella tertiolecta (Chlorophyceae). J Phycol 25:80-78

Brown BE, Le Tissier MDA, Bythell JC (1995) Mechanisms of bleaching deduced from histological studies of reef corals during a natural bleaching event. Mar Biol 122:655-663

Cayan D (1992) Latent and sensible heat flux anomalies over the northern oceans: the connection to monthly atmospheric circulation. J Clim 5:354-369

Coffroth MA, Lasker HR, Diamond ME, Bruenn JA, Bermingham E (1992) DNA fingerprints of a gorgonian coral-a method for detecting clonal structure in a vegetative species. Mar Biol 114:317-325

Dustan P (1982) Depth-dependent photoadaptation by zooxanthellae of the reef coral Montastrea annularis. Mar Biol 68:253-264

Fagoonee I, Wilson HB, Hassell MP, Turner JR (1999) The dynamics of zooxanthellae populations: a long-term study in the field. Science 283:843-845

Falkowski PG, Dubinsky Z (1981) Light-shade adaptation of
Stylophora pistillata, a hermatypic coral from the Gulf of Eilat. Nature 289:172-174

Fitt WK, McFarland FK, Warner ME, Chilcoat GC (2000) Seasonal patterns of tissue biomass and densities of symbiotic dinoflagellates in reef corals and relation to coral bleaching. Limnol Oceanogr 45:677-685

Gorbunov MY, Kolber ZS, Lesser MP, Falkowski PG (2001) Photosynthesis and photoprotection in symbiotic corals. Limnol Oceanogr 46:75-85

Grasshoff K, Kremling K, Ehrhardt M (1999) Methods of seawater analysis, 3rd edn. Wiley VCH, Weinheim, Germany

Harley CDG, Hughes AR, Hultgren KM, Miner BG and others (2006) The impacts of climate change in coastal marine systems. Ecol Lett 9:228-241

Hoegh-Guldberg O, Smith PG (1989) The effect of sudden changes in temperature, light and salinity on the population density and export of zooxanthellae from the reef corals Stylophora pistillata Esper and Seriatopora hystrix Dana. J Exp Mar Biol Ecol 129:279-303

Iglesias-Prieto R, Beltran VH, LaJeunesse TC, Reyes-Bonilla $H$, Thome PE (2004) Different algal symbionts explain the vertical distribution of dominant reef corals in the eastern Pacific. Proc R Soc Lond B Biol Sci 271:1757-1763

Jeffrey SW, Humphrey GF (1975) New spectrophotometric equations for determining chlorophylls $\mathrm{a}, \mathrm{b}$ and $\mathrm{c}_{2}$ in higher-plants, algae and natural phytoplankton. Biochem Physiol Pflanz 167:191-194

Johannes RE, Wiebe WJ (1970) A method for determination of coral tissue biomass and composition. Limnol Oceanogr 21:540-547

> Jones RJ (1997) Zooxanthellae loss as a bioassay for assessing stress in corals. Mar Ecol Prog Ser 149:163-171

Karako-Lampert S, Katcoff DJ, Achituv Y, Dubinsky Z, Stambler N (2004) Do clades of symbiotic dinoflagellates in scleractinian corals of the Gulf of Eilat (Red Sea) differ from those of other coral reefs? J Exp Mar Biol Ecol 311: 301-314

Kuguru B, Winters G, Beer S, Santos SR, Chadwick NE (2007) Adaptation strategies of the corallimorpharian Rhodactis rhodostoma to irradiance and temperature. Mar Biol 151:1287-1298

LaJeunesse TC (2001) Investigating the biodiversity, ecology, and phylogeny of endosymbiontic dinoflagellates in the genus Symbiodinium using the ITS region: in search of a 'species' level marker. J Phycol 37:866-880

> LaJeunesse TC (2002) Diversity and community structure of symbiotic dinoflagellates from Caribbean coral reefs. Mar Biol 141:387-400

LaJeunesse TC, Loh WKW, van Woesik R, Hoegh-Guldberg O, Schmidt GW, Fitt WK (2003) Low symbiont diversity in southern Great Barrier Reef corals, relative to those of the Caribbean. Limnol Oceanogr 48:2046-2054

- Lesser MP, Gorbunov MY (2001) Diurnal and bathymetric changes in chlorophyll fluorescence yields of reef corals measured in situ with a fast repetition rate fluorometer. Mar Ecol Prog Ser 212:69-77

> Loya Y (1972) Community structure and species diversity of hermatypic corals at Eilat, Red Sea. Mar Biol 13:100-123

> Loya Y (1976) The Red Sea coral Stylophora pistillata is an rstrategist. Nature 259:478-480

> Marubini F, Davies PS (1996) Nitrate increases zooxanthellae population density and reduces skeletogenesis in corals. Mar Biol 127:319-328

> Mass T, Einbinder S, Brokovich E, Shashar N, Vago R, Erez J, Dubinsky Z (2007) Photoacclimation of Stylophora pistillata to light extremes: metabolism and calcification. Mar Ecol Prog Ser 334:93-102 
Prezelin BB (1987) Photosynthetic physiology of dinoflagellates. In: Taylor FJR (ed) The biology of dinoflagellates, Vol 21. Blackwell Scientific Publications, Oxford, p 174-223

Rinkevich B, Loya Y (1979) The reproduction of the Red Sea coral Stylophora pistillata. 1. Gonads and planulae. Mar Ecol Prog Ser 1:133-144

Rowan R (2004) Thermal adaptation in reef coral symbionts. Nature 430:742

Rowan R, Knowlton N (1995) Intraspecific diversity and ecological zonation in coral algal symbiosis. Proc Natl Acad Sci USA 92:2850-2853

Shenkar N, Fine M, Kramarsky-Winter E, Loya Y (2006) Population dynamics of zooxanthellae during a bacterial bleaching event. Coral Reefs 25:223-227

Stimson J, Kinzie RA (1991) The temporal pattern and rate of release of zooxanthellae from the reef coral Pocillopora damicornis (Linnaeus) under nitrogen-enrichment and control conditions. J Exp Mar Biol Ecol 153:63-74

Swofford DL (2002) PAUP: Phylogenetic Analysis Using Parsimony (and other methods) 4.0 Beta. Sinauer Associates, Sunderland, MA

Thompson JD, Gibson TJ, Plewniak F, Jeanmougin F, Higgins DG (1997) The CLUSTAL_X windows interface: flexible strategies for multiple sequence alignment aided by quality analysis tools. Nucleic Acids Res 25:4876-4882

Editorial responsibility: Otto Kinne,

Oldendorf/Luhe, Germany
Titlyanov EA, Titlyanova TV, Yamazato K, van Woesik R (2001) Photo-acclimation dynamics of the coral Stylophora pistillata to low and extremely low light. J Exp Mar Biol Ecol 263:211-225

Trench RK (1993) Microalgal-invertebrate symbioses-a review. Endocytobiosis Cell Res 9:135-175

von Holt C, von Holt M (1968) Transfer of photosynthetic products from zooxanthellae to coelenterate hosts. Comp Biochem Physiol 24:73-81

Warner ME, Chilcoat GC, McFarland FK, Fitt WK (2002) Seasonal fluctuations in the photosynthetic capacity of photosystem II in symbiotic dinoflagellates in the Caribbean reef-building coral Montastraea. Mar Biol 141:31-38

Warner ME, LaJeunesse TC, Robison JD, Thur RM (2006) The ecological distribution and comparative photobiology of symbiotic dinoflagellates from reef corals in Belize: potential implications for coral bleaching. Limnol Oceanogr 51:1887-1897

Weinberg S (1976) Submarine daylight and ecology. Mar Biol 37:291-304

Winters G, Loya Y, Rottgers R, Beer S (2003) Photoinhibition in shallow-water colonies of the coral Stylophora pistillata as measured in situ. Limnol Oceanogr 48:1388-1393

Winters G, Loya Y, Beer S (2006) In situ measured seasonal variations in $F_{\mathrm{v}} / F_{\mathrm{m}}$ of 2 common Red Sea corals. Coral Reefs 25:593-598

Submitted: February 13, 2008; Accepted: March 26, 2009

Proofs received from author(s): May 14, 2009 